\title{
THE FREQUENCY OF HEART RHYTHM DISORDERS IN PREHOSPITAL PHASE OF ACUTE CORONARY SYNDROME
}

\author{
Jasna Milutinović-Puača, Slađana Anđelić
}

Prehospital management of patients with acute coronary syndrome (ACS) is the essential element which influences the survival of patients and the outcome of the disease. Most lethal outcomes occur within the first hour after the onset of acute myocardial infarction (AMI), and the usual cause is some of heart rhythm and conduction disorder.

Aim. To assess the frequency of each form of ACS, and the incidence of the development of rhythm and conduction disorders during the first $12 \mathrm{hrs}$ in relation to the localization of ACS and disease outcome.

Material and methods. We analyzed prospectively 107 patients transported under continual ECG monitoring to the Coronary Unit after ACS diagnosed prehospitally by the team of the Belgrade Emergency Medical Services. AMI localization was detected and the development of rhythm (supraventricular and ventricular), and conduction disorders were followed by prehospital ECG monitoring. Patients outcome was under follow-up until discharge from hospital.

Results. Acute ST-elevation myocardial infarction (STEMI), both anterior and diaphragmatic, is most frequent in men aged $50-59$ years. There were no statistically significant differences in the occurrence of heart rhythm and conduction disorders both in the STEMI and non-STEMI (NSTEMI) groups. The most frequent rhythm disorders during the first $4 \mathrm{hrs}$ after STEMI onset were sinus bradycardia, sinus tachycardia and ventricular tachycardia, while atrial fibrillation and single ventricular extrasystole were most frequent after 5-12 hrs. In STEMI, AV blocks occurred exclusively during the first $4 \mathrm{hrs}$, while bundle branch blocks occurred statistically more significantly during the first $4 \mathrm{hrs}$. Sinus bradycardia and atrioventricular blocks were statistically significantly associated with diaphragmatic STEMI. In this localization there were no bundle branch blocks. The most frequent rhythm disorder associated with anterior STEMI was sinus tachycardia that occurred exclusively during the first $4 \mathrm{hrs}$. The occurrence of ventricular tachycardia and ventricular fibrillation in any of STEMI locations was statistically more significant in the first 4 hrs after complaints onset. In the studied group of patients with ACS mortality rate was $12,1 \%$, while in the group of STEMI patients it was $11 \%$, with a significant frequency of infarction with anterior localization and bundle branch block in men.

Conclusion. Future studies should be directed toward identifying methods, as precise as possible, for early screening of heart rhythm and conduction disorders in ACS so as to enable a timely, preventive and therapeutic management.

Russ J Cardiol 2014, 4 (108), Engl.: 15-21

Key words: acute coronary syndrome, disorder, rhythm, conduction, prehospital. Emergency Medical Services, Belgrade, Serbia.

Corresponding author. Andjelic Sladjana, MD, PhD. Aleksinackih rudara 25/4 Street, 11070 New Belgrade, Serbia. Tel.: +381641245757, e-mail: novizivot@ptt.rs

Received December 21, 2013

Revision received December 25, 2013.

Accepted January 13, 2014

\section{ЧАСТОТА СЕРДЕЧНОГО РИТМА НА ДОГОСПИТАЛЬНОМ ЭТАПЕ ОСТРОГО КОРОНАРНОГО СИНДРОМА}

\author{
Jasna Milutinović-Puača, Slađana Anđelić
}

Догоспитальный этап лечения пациентов с острым коронарным синдромом (ОКС), является существенным элементом, который влияет на выживаемость больных, и исход болезни. Большинство летальных исходов происходит в течение первого часа после начала острого инфаркта миокарда (ОИМ), и обычная причина - расстройства сердечного ритма и проводимости.

Цель. Оценить частоту каждого вида ОКС, развитие расстройств нарушения ритма и проводимости в течение первых 12 часов, по отношению к локализации ОКС и исхода заболевания.

Материал и методы. Мы проспективно проанализировали 107 пациентов, помещенных под непрерывный мониторинг ЭКГ в коронарном отделении после диагностирования у них ОКС бригадой врачей скорой медицинской помощи в больнице Белграда. На догоспитальном этапе мониторинга ЭКГ было обнаружено наличие ОИМ и развитие ритма (наджелудочкового и желудочкового), нарушение проводимости. Пациенты были под наблюдением до выписки из больницы.

Результаты. Острый подъем сегмента ST при инфаркте миокарда (ИМ с ST), как при переднем, так при диафрагмальном, наиболее часто встречается у мужчин в возрасте 50-59 лет. Отсутствуют статистически значимые различия в распространенности нарушений ритма сердца и расстройств проводимости, как при ИM с ST, так и при ИМ без поднятия сегмента ST (ИМ без ST). Наиболее частыми нарушениями ритма в течение первых 4 часов после ИМ с ST были синусовая брадикардия, синусовая тахикардия, желудочковая тахикардия, в то

\section{Introduction}

Different presentations of acute coronary syndrome (ACS) share identical pathophysiological substrate. The diagnosis of ACS, i.e. acute myocardial infarction (AMI) as the most severe form of this syndrome, is passed with время как мерцательная аритмия и одиночная желудочковая экстрасистолия были наиболее частыми после 5-12 часов. При ИМ с ST атриовентрикулярная блокада, как и блокада ножки пучка Гиса происходила исключительно в течение первых 4 часов. Синусовая брадикардия и атриовентрикулярная блокада были статистически значимо связаны с диафрагмальным ИM c ST. При этой локализации не было блокады ножки пучка Гиса. Наиболее частым нарушением ритма связанным с передним ИМ с ST, была синусовая тахикардия, которая проявлялась исключительно в течение первых 4 часов. Возникновение желудочковой тахикардии и фибрилляции желудочков при любой локализации ИМ с ST было статистически более значимым в первые 4 ч после начала жалоб. В обследованной группе больных с ОКС смертность составила $12,1 \%$, в то время как в группе пациентов с ИМ с ST она была $11 \%$, со значительной частотой поражения миокарда передней локализации и блокады ножки пучка Гиса у мужчин.

Вывод. Будущие исследования должны быть направлены на выявление методов, для, как можно точнее, раннего скрининга сердечного ритма и нарушений ритма и проводимости при ОКС, с тем, чтобы обеспечить своевременное, профилактическое и терапевтическое лечение.

\section{Российский кардиологический журнал 2014, 4 (108), Англ.: 15-21}

Ключевые слова: острый коронарный синдром, расстройство ритма, проводимость, догоспитальный этап.

high probability if evolutionary changes are present in two out of the following three criteria: clinical features, ECG or biochemical markers of myocardial necrosis [1]. The main symptom that initiates the diagnosis is chest pain; however, the classification of patients is based on ECG 
findings. Accordingly, there are two categories of patients: patients with typical acute chest pain and persistent $(>20$ min) ST-segment elevation (STE-ACS) that most develop ST-segment myocardial infarction (STEMI), and patients with acute chest pain but without ST-segment elevation (NSTE-ACS). At first presentation these patients develop ST-segment depression or T-wave inversion, low-voltage T-waves or they are without ECG changes at first presentation. In Serbia STEMI is more frequent and has a moderately higher rate of mortality than NSTE-ACS (7\%:5\%), but after 6 months the rates of both conditions are very similar (12\%:13\%).

ACS is a wide spectrum of clinical manifestations caused by a sudden reduction in supply of a portion of myocardial $\mathrm{O} 2$ caused by the disruption of unstable atherosclerotic plaque with consequent thrombosis, vasoconstriction and distal microembolization. Prevention of acute coronary event, early identification of ACS, rapid and effective prehospital treatment enable preservation of functional myocardium, which correlates to the decrease of morbidity and mortality from AMI [2]. A number of studies have shown the significance of rapid ACS symptoms recognition, early activation of healthcare system, and if necessary, early cardiopulmonary resuscitation, rapid prehospital diagnostics, triage, adequate treatment and transport (with monitoring of patient s vital parameters) [3]. As the result of these studies guidelines for the treatment of patients with chest pain as well as the guidelines for the management of patients with ACS have been formed. In 2010 the American Heart Association (AHA), the International Liaison Committee on Resuscitation (ILCOR) and the European Council Resuscitation (ERC) published guidelines that paid special attention to the prehospital treatment of patients with ACS [4]. The presence of a protocol for the management of such patients helps doctors in decision making when meeting the patient for the first time, and in suspecting and/or passing the diagnosis of ACS.

ACS can become complicated in each phase of the disease, and particularly during the first several hours after symptoms onset of ventricular rhythm disorders, primarily ischemic ventricular fibrillation (VF). Therefore, the physician s first task is to help the patient survive, i.e. eliminate heart rhythm disorder which is the most frequent cause of lethal outcome.

The aim of the study was to determine the frequency of different forms of ACS and the incidence of the development of heart rhythm and conduction disorders during the first $12 \mathrm{hrs}$ of AMI related to MI localization, as well as the disease outcome.

\section{Material and methods}

A prospective study involved 107 patients treated at the Coronary Unit of the Clinical Centre of Serbia after prehospitally passed diagnosis of ACS and under continual ECG monitoring by the Belgrade EMS. The prehospital diagnosis was made based on two out of three known criteria: typical anginal pain in duration of at least 30 minutes, typical ECG features of ST-segment elevation in two consecutive leads (in AMI with ST-segment elevation) as well as ST-segment depression in several leads (in unstable angina - UNA and AMI without ST-segment elevation). It was not possible to the increase of cardiospecific enzymes due to the lack of a rapid test.

The patients were examined at the site of event (residence, working place, public place), and after passed diagnosis and initiated treatment, were transported to the Centre Coronary Unit of the Clinical Center of Serbia under continual ECG monitoring by the team, composed of a physician, medical technician and driver of the Belgrade Emergency Medical Services. On admission all patients were continually monitored, and ECG was performed at least once daily.

Prehospital ECG was used to determine AMI localization, and to analyze the development of the following heart rhythm disorders: 1/ supraventricular: sinus tachycardia (ST), sinus bradycardia (SB), supraventricular extrasystole (SVES), atrial flatter (AFL), atrial fibrillation (AF), and 2/ ventricular: ventricular extrasystole (VES) - single, in pairs and polymorphic, $\mathrm{R} / \mathrm{T}$ phenomenon, ventricular tachycardia (VT) and ventricular fibrillation (VF), and conduction disorders (AV blocks, bundle branch blocks). Patients' outcome until discharge from hospital was under follow-up.

The collected data were statistically analyzed using SPSS 10.0 for Windows. In the analysis of the data the following statistical methods were used: arithmetic mean and standard deviation, while in the assessment of statistical significance regarding differences in the frequency of distribution Chi-square test and Student's t-test were used. By using the method of two-way analysis of variance (ANOVA) for proportions we tested the significance of frequency difference of various categories of rhythm disorders in relation to MI localization and time. A statistically significant difference was represented by $p<0.05$. In the presentation of the obtained results Word for Windows-6.0 was used. The observed characteristics are presented by histogram frequency, circular graph for frequencies and column diagram for frequencies.

\section{Results}

Over a 6-months period 217 patients were transported by the Belgrade EMS team to the Coronary Unit of the Clinical Centre of Serbia, all diagnosed with ACS of whom $124(57,14 \%)$ were hospitalized. The studied group of 107 ACS patients, $60.7 \%$ male and 39,3\% female, all of whom had a complete illness history. The distribution of ACS is shown on Figure 1.

ACS was most frequent in men aged 50-59 years $(33,9 \%)$, and less in women aged 30-49 years (20\%). Women develop the disease only after 50 years of age. According to the localization of STEMI, diaphragmal was 
more frequent $(53,66 \%)$ than anterior $(42,69 \%)$ or combined localization (3.65\%). Among diaphragmal STEMI, 16 (36.4\%) also had right ventricular infarction. Anterior STEMI was more frequent in men $(65,7 \%)$ than in women $(34 \%)(p<0,05)$, as well as infarction of diaphragmal localization (men $56,8 \%$, women $43,2 \%$ ). Its occurrence predominates in men aged $40-59$ years $(43,6 \%)$ and in women aged $60-79$ years $(83,4 \%)$. Heart rhythm and conduction disorders were detected in 74/107 $(69,1 \%)$ ACS and in 63/82 (76,8\%) STEMI. As obserevd, there was a statistically sigificant association between heart rhythm and STEMI $(79,8 \%, \mathrm{p}<0,05)$ (method of parametric Spearman correlation) (Table 1). Conduction disorder detected in 22/107 (21,5\%) patients with ACS (Table 1) presents a significant association of conduction disorder with STEMI $(68,2 \%, \mathrm{p}<0,05)$. However, by comparing the frequency of heart rhythm and conduction disorders between the patients with STEMI and other groups, i.e. non-STEMI (NSTEMI), unstabile angina pectoris (UAP) and reinfarction (ReInf) there were no statistically significant differences $(p>0,05)$ (Table 2). Therefore, in a further study heart rhythm and conduction disorders were under follow-up, independently of the type of ACS.

By analyzing the occurrence of supraventricular rhythm disorder in STEMI during the first $4 \mathrm{hrs}$ and in the period from 5-12 hrs from AMI onset, the trend of SB $(247,7 \%)$ and ST $(40,9 \%)$ development during the first $4 \mathrm{hrs}$ was observed, while AF (registered in 9; $64.3 \%$ of patients) was most frequent in the period from 5-12 hrs (Figure 2). The occurrence of SVES and AFL was not registered in the period of $12 \mathrm{hrs}$ from the AMI onset.

Among ventricular disorders in STEMI, VT was most frequent $(35,3 \%)$ during the first $4 \mathrm{hrs}$. VF and single VES were equally frequent $(23,5 \%)$, while VES in pairs was present in $17,7 \%$ patients. In the period 5-12 hrs from AMI onset, single VES were most frequent, in 6/9 patients with ventricular rhythm disorders. Polymorphic VES and VES with $\mathrm{R} / \mathrm{T}$ phenomenon were not registered in the observed group of patients during the first $12 \mathrm{hrs}$ from AMI onset (Figure 3).
By analyzing heart conduction disorders in STEMI a statistically more significant frequency of bundle branch blocks (BBB) was observed in relation to AV blocks (10:5). AV blocks occurred only during the first $4 \mathrm{hrs}$, while the frequency of BBB was statistically more significant during the first $4 \mathrm{hrs}$ in $8(80,0 \%)$ patients. Figure 4 presents the frequency of each form of heart rhythm and conduction disorders where it can be observed that SB was the most frequent rhythm disorder in STEMI $(24,2 \%)$ followed by ST with 20,2\%.

In the first $4 \mathrm{hrs}$ there was $74,75 \%$ rhythm and conduction disorders, while in the $5-12 \mathrm{hrs}$ period there was 25,25\% disorders (Figure 5).

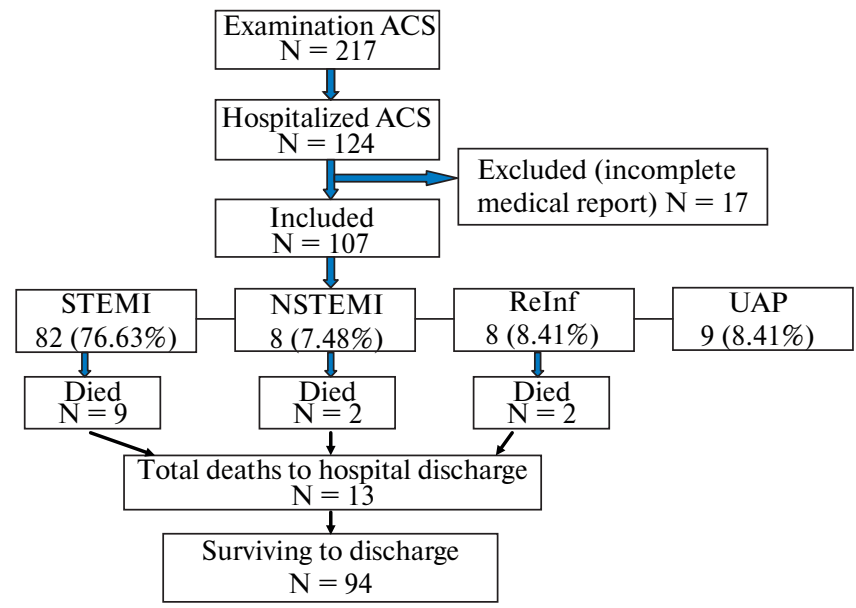

Figure 1. Flow diagram of patients with acute coronary syndrome.

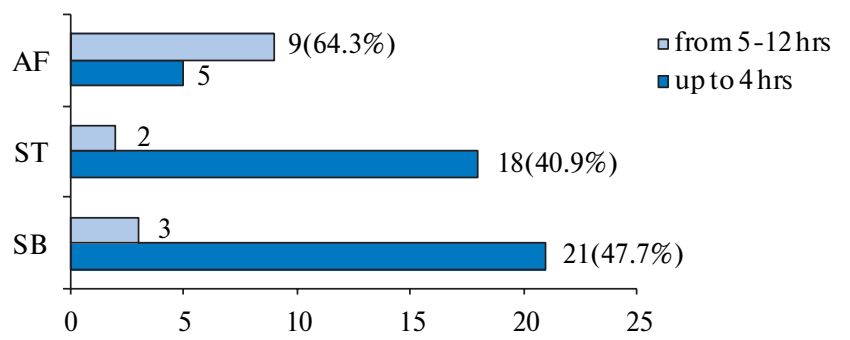

Figure 2. Supraventricular rhythm disorders in STEMI according to onset occurrence.

Abbreviations: AF - atrial fibrillation, ST - sinus tachycardia, SB - sinus bradycardia.

Table 1

Frequency of rhythm and conduction disorders in relation to single forms of ACS

\begin{tabular}{|c|c|c|c|c|c|}
\hline Rhythm disorder & $\begin{array}{l}\text { STEMI } \\
\text { (n) }\end{array}$ & $\begin{array}{l}\text { NSTEMI } \\
\text { (n) }\end{array}$ & $\begin{array}{l}\text { UAP } \\
\text { (n) }\end{array}$ & $\begin{array}{l}\text { Relnf } \\
\text { (n) }\end{array}$ & $\begin{array}{l}\text { Total } \\
\text { (n) }\end{array}$ \\
\hline Supraventricular & 39 & 2 & 5 & 4 & 50 \\
\hline Ventricular & 6 & - & - & - & 6 \\
\hline Combined & 14 & 3 & & 1 & 18 \\
\hline Total & 59 & 5 & 5 & 5 & 74 \\
\hline Conduction disorder & $\begin{array}{l}\text { STEMI } \\
\text { (n) }\end{array}$ & $\begin{array}{l}\text { NSTEMI } \\
(\mathrm{n})\end{array}$ & $\begin{array}{l}\text { UAP } \\
\text { (n) }\end{array}$ & $\begin{array}{l}\text { Relnf } \\
\text { (n) }\end{array}$ & $\begin{array}{l}\text { Total } \\
\text { (n) }\end{array}$ \\
\hline Atrioventricular (AV) & 5 & - & 1 & - & 6 \\
\hline Bundle brunch block (BBB) & 10 & - & 2 & 3 & 15 \\
\hline Combined & - & 1 & - & - & 1 \\
\hline Total & 15 & 1 & 3 & 3 & 22 \\
\hline
\end{tabular}


Follow-up of each form of bradyarrythmia in relation to STEMI localization revealed that SB was the most frequent rhythm disorder associated with diaphragmal MI, with statistical significance of $p<0,05$, while BBB was highly significantly associated with anterior STEMI, with

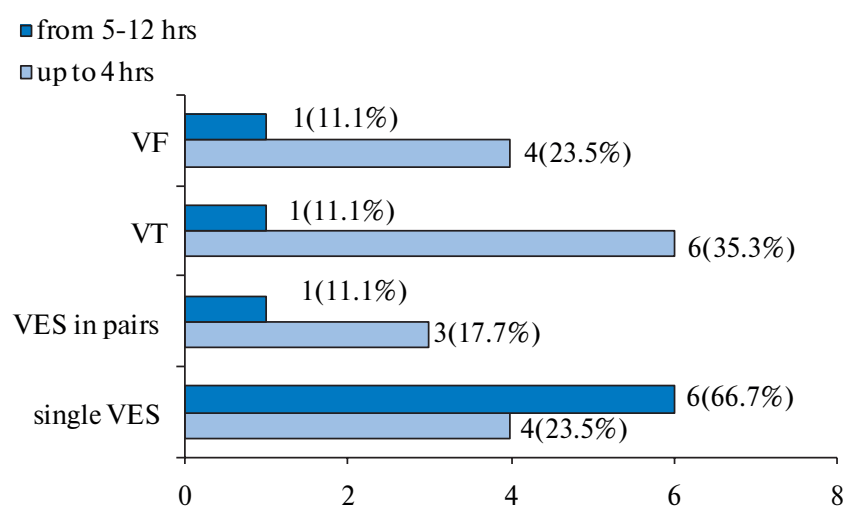

Figure 3. Ventricular heart disorders in STEMI according to onset.

Abbreviations: VF-ventricular fibrillation, VT-ventricular tachycardia, VESventricular extrasystole.

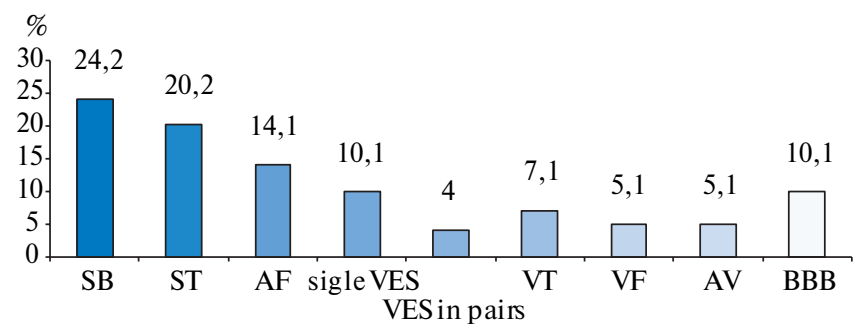

Figure 4. Distribution of heart rhythm and conduction disorders in STEMI. Abbreviations: BBB-Bundle Brunch Blocks, AV-atrioventricular.

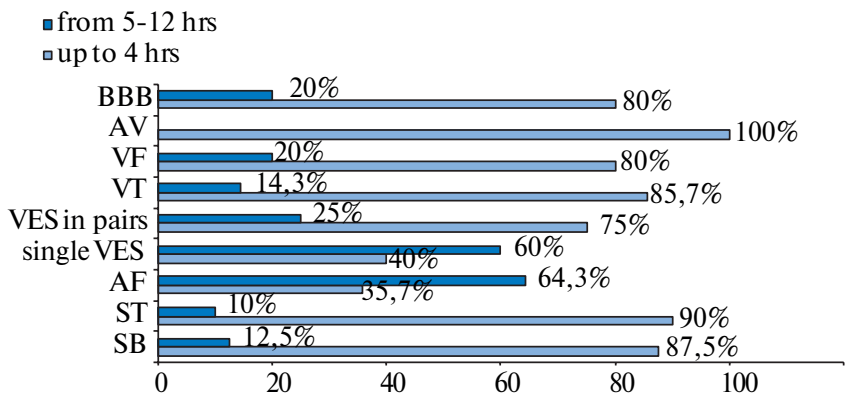

Figure 5. Distribution of rhythm and conduction disorders according to the time of onset in STEMI. statistical significance of $p<0,05$, while BBB was highly statistically significantly associated with anterior STEMI $(p<0,01)$. A statistically significant frequency was revealed regarding the occurrence of $\mathrm{AV}$ blocks in diaphragmal STEMI.

In the anterior STEMI, among bradyarrhythmias only $\mathrm{SB}$ and AV blocks were present in the first $4 \mathrm{hrs}$, while the occurrence of BBB was statistically more significant in the first $4 \mathrm{hrs}$ in relation to the period of 5-12 hrs. Using the method of two-factor ANOVA to analyze proportions, we tested the significance of difference in the frequency of various categories of rhythm disorders in relation to the AMI localization and time of onset; consequently, we detected that the most frequent and most expected form in the first $4 \mathrm{hrs}$ was SB rhythm disorder and that it was associated with diaphragmal STEMI $(p<0,05)$, while AV blocks occurred only during the first $4 \mathrm{hrs}$, whereas BBB did not occur in STEMI of diaphragmal localization.

The analysis of each form of tachycardia in the anterior and diaphragmal localization of AMI revealed that tachyarrhythmias were more frequent in the anterior STEMI, i.e. that ST was most frequent of rhythm disorders associated with anterior localization of infarction with statistical significance of $p<0,05$. Single VES were more frequent in the diaphragmal STEMI. Almost identical frequency was that of VT in both localizations, while VF was statistically significantly present in the anterior STEMI (Figure 6).

By observing the frequency of tachyarrythmias in relation to the localization of AMI according to the time of onset, we revealed that in the first $4 \mathrm{hrs}$ ST occurred exclusively in 14 patients and that it was significantly associated with STEMI $(p<0,05)$. VT was present in 4 patients in the anterior STEMI during the first $4 \mathrm{hrs}$ only, while AF was more present in the 5-12 hrs period. By analyzing the frequency of certain forms of tachyarrhythmias in diaphragmal STEMI, it was revealed that in the first $4 \mathrm{hrs}$ ST was more frequent and that single VES were more frequent in the period 5-12 hrs. The occurrence of VF in the diaphragmal STEMI was registered in the first 4 hrs only.

Thirteen $(12,1 \%)$ ACS patients died before being discharged from hospital, of whom 9 with STEMI (6 with anterior and 3 with diaphragmal localization), 2 with NSTEMI and 2 with ReInf, while in the UAP group there was no lethal outcome (Figure 7). In STEMI, total mortality rated $11 \%$. Most lethal endings were in patients

Table 2

Frequency and statistical significance of rhythm and conduction disorders in relation to STEMI and other groups

\begin{tabular}{|l|l|l|l|l|}
\hline Heart rhythm and conduction disorders & STEMI & Other groups & No \\
\hline With & No & 6 & 19 \\
\hline Without & 63 & 76.80 & 76 \\
\hline Total & 19 & 23.20 & 24 \\
\hline
\end{tabular}


with BBB (33.3\%), and slightly less in those with VF and ST (22/2\% in each). In the group of patients with NSTEMI and ReInf who died, those with $\mathrm{AF}$ and $\mathrm{BBB}$ were equally represented (one of each). In 13 ACS patients who died, supraventricular rhythm disorders were present in 4 $(30,8 \%)$, ventricular in $3(23 \%)$, and conduction disorders in $6(46,2 \%)$ patients. The most frequent rhythm disorder registered in 5 patients who died BBB.

\section{Discusion}

Prehospital healthcare of patients with ACS is an essential element that influences the survival of patients and the outcome of disease. Most lethal outcomes occur within the first hour since AMI onset, and usually the cause is some of rhythm (VF) or conduction (asystole) disorders. In our paper, of the total number of ACS $76,63 \%$ had STEMI. According to the database of the National Registry for ACS (REACS), in 2003 there was $52,7 \%$, in $200451,8 \%$ [5] and in $200550 / 7 \%$ of STEMI patients on admission, which is considerably lower in relation to our study results. Although according to this registry the rate of STEMI indicates the tendency of mild decrease, it is still significantly higher as related to the data of the European countries registry, for example in the GRACE study [6] there is about $42 \%$ of STEMIs. This most severe form of ACS has also the highest hospital mortality rate. Better diagnostics and organization of healthcare services would probably also decrease the number of patients with STEMI and increase the number of NSTEMIs.

In our study there was more men than women $(60,7 \%: 39.3 \%)$ with ACS. Similarly to our results, according to the data of REACS in Serbia the number of men with ACS was higher: in 200362,7\%, in 200463,1\%, and in $200563 \%$. In EHS-ACS-II study [7], there were $70 \%$ of men with ACS, and in the GRACE study $72 \%$ [6].

The frequency of ACS development rises with age. In persons aged 40-70 years ACS is diagnosed more frequently than in women, while in those aged over 70 years the rate in both gender is mostly identical.

Heart arrhythmias are usually manifested during ACS, while the type of arrhythmia depends on the form of ACS. In almost $90 \%$ of patients who survived AMI, some of the forms of rhythm disorder were disclosed; while according to a study by Perron et al. [8] 25\% had conduction disorder in the first $24 \mathrm{hrs}$ since the onset of AMI. In our study $69,1 \%(74 / 107)$ of patients with ACS had heart rhythm and conduction disorders, while heart rhythm and conduction disorders occurred in 76,8\% (63/82) of STEMI patients. Conduction disorder was present in 18,3\% $(15 / 82)$ of patients, and rhythm disorder in $72 \%$, which is similar to Meltzers results according to which the frequency of rhythm disorders in AMI was 72-96\% [9], while Perron et al [8] obtained much lower rate results.

In STEMI patients $74,75 \%$ of rhythm and conduction disorders occurred within the first $4 \mathrm{hrs}$, and $25.25 \%$ from

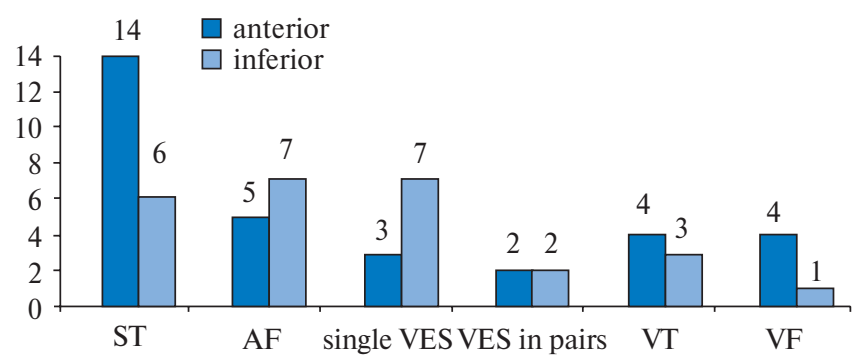

Figure 6. Distribution of tachyarrhythmia in STEMI of anterior and diaphragmal localization.

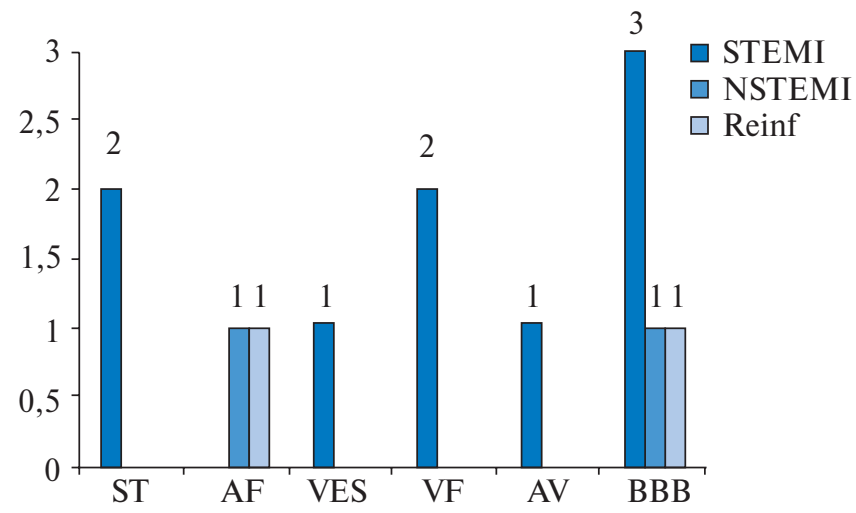

Figure 7. Distribution of lethal outcome in relation to rhythm and conduction disorders.

5-12 hrs after AMI onset. Supraventricular rhythm disorders developed in 64,6\% (53/82) of patients with STEMI. By analyzing the frequency of supraventricular rhythm disorders in relation to the time elapsed since AMI occurrence, the most frequently registered were SB with $47,7 \%$ $(21 / 44)$ and ST with $40,9 \%(18 / 44)$ of patients in the first 4 hrs, while AF was most frequent rhythm disorder within 5-9 hrs with 63,3\% (9/44) registered patients. Branwald [10] reported that SB occurred in $25-40 \%$ of patients within the first hour after infarction and in $15-20 \%$ within the first 4 hrs.

In our study rhythm and conduction disorders in STEMI were registered in $14.1 \%$ of patients, while data from the literature vary from $10-20 \%$ [10], i.e. $5-23 \%$ [11]. According to the data from the GISSI-3 study [12] the incidence of $\mathrm{AF}$ is $7,8 \%$ and it is associated with the indicators of poor prognosis: patient s age ( $>70$ years), female gender, Killip class III/IV, previous AMI, hypertension, high systolic arterial pressure on admission, diabetes mellitus as well as VT and VF. Sugi [13] recommends the application of amiodarone in the prevention of $\mathrm{AF}$ episode relapses after cardioversion. In their study on atrial arythmias during the first hours of AMI, Kyriakidis et al. [14] reported that most supraventricular arrhythmias was ischemia of the left and right atrium, and all cases had blood vessel occlusion with compromised blood supply to $\mathrm{AV}$ node. Ischemia of sinoatrial (SA) node was one of the basic causes of AF. None of the patients with SB had arte- 
rial occlusion of the SA node. Bradycardia was the result of increased vagal tone.

Ventricular rhythm disorders were recorded in 24,4 $(20 / 82)$ of STEMI patients, while ventricular rhythm disorders were most frequent in single VES with 38.5\% $(10 / 26)$ of patients, then VT in $26,9 \%(7 / 26)$ and VF in $19,2 \%(5 / 26)$. By the analysis of ventricular rhythm disorders we confirmed that they were most frequent in the first $4 \mathrm{hrs}$ since AMI onset. At that period there were $65,4 \%$ $(17 / 26)$ ventricular rhythm disorders, among which VT was most frequent with $35,3 \%(6 / 17)$ of patients. According to Braunwald, about $60 \%$ of VF episodes occur within the first $4 \mathrm{hrs}$ and about $80 \%$ within $12 \mathrm{hrs}$ from AMI onset, while non-sustained paroxysmal VT, either monomorphic or polymorphic, and occur in $67 \%$ of patients monitored within the first $12 \mathrm{hrs}$ after infarction [10]. In our study there were $80 \%$ of VF episodes in the first $4 \mathrm{hrs,}$ which is in accordance with the results by VasiljevićPokrajčić Z. and Stefanović B. [15].

Primary VF occurs suddenly and unexpectedly in patients with or without minimal signs of cardiac failure; it also occurs in over $10 \%$ of hospitalized patients with AMI [11]. Antman [10] reports that primary VF occurs in 3-5\% of patients during hospitalization [10], which is similar to the results by Perron et al. (4,5\%) [8]. GISSI-1 study [12] VT is registered in $3,5 \%$ and VF in $4,1 \%$ of patients, while in our study VT was registered in $7.1 \%$ and VF in $5,1 \%$ of patients.

Conduction disorders were present in 18,3\% (15/82) of STEMI patients, while BBB were most frequent particularly in the first $4 \mathrm{hrs}$ after AMI onset, i.e. in 53,3\% (8/15) of patients. AV bundle blocks occurred only during the first $4 \mathrm{hrs}$, i.e. in $33,3 \%(5 / 15)$ of patients.

The occurrence of bradycardia in diaphragmal STEMI is $30 \%$, while in our study it was $57,9 \%(22 / 38)$ [17]. By analyzing the occurrence of single forms of bradyarrhytmia in STEMI related to the MI localization and onset time, the most frequent form of rhythm disorder in the infarction of diaphragmal localization was SB as well as the most expected one within the first $4 \mathrm{hrs}$. According to data from the literature it occurs in $10-15 \%$ of MI patients, i.e. in up to $40 \%$ of infarction with diaphragmal localization, while in our study it occurred in $78,2 \%$ $(18 / 22)$ of diaphragmal STEMI. SB is a more frequent rhythm disorder in infarctions of inferior and posterior localization, which explains the fact that a higher number of receptors responsible for cholinergic stimulation are localized in the inferoposterior wall of the left ventricle which, when stimulated, triggers bradycardia and hypotension. These are manifestations of Bezold-Jarisch reflex which is induced by vagal stimulation, particularly in occlusion of the right coronary artery. SB can be occasionally caused by pain or morphine usage and lead to vasovagal syncope. SB occurring $6 \mathrm{hrs}$ after AMI onset is most often transitory and caused by sinus node dysfunction or atrial ischemia. In a very early phase of AMI this arrythmia can lead to the development of repetitive ventricular arrhythmias and hypotension on one hand and on the other to the reduction in myocardial oxygen demand.

In the TIMI II Trial, which analyzed the occurrence of bradyarrhythmia in diaphragmal localization of MI treated with thrombolytic therapy, the frequency of AV block was $12 \%$, and in prethrombolytic phase even $20 \%$. In our study the frequency of $\mathrm{AV}$ blocks in diaphragmal localization of MI was slightly lower, i.e. 10,52\% (4/38). BBB occurred only in MI of anterior localization and more frequently in the first $4 \mathrm{hrs}$.

According to Uznańska-Loch et al. [18], in diaphragmal infarction AV block can suddenly occur without the introduction of first degree $\mathrm{AV}$ block, and within the first 6 hours after the onset of symptoms, while the block itself usually reacts well to atropine administration. Patients with a later AV block development, usually after 24 hrs, are resistant to atropine and require the application of electrostimulation. The authors consider that the early AV block is the result of vagotomy, while the late one is caused by ischemia and it can be resolved gradually concurrently with the decrease of ischemia.

Myocardial ischemia can cause blocks at any level of the conduction system, atrioventricular and/or intravetricular. According to data from the literature, BBB can occur in $5-10 \%$ of AMI patients [10], while in our study they occurred only in patients with anterior infarction ( $10 \%$ of cases of the total number of patients with rhythm and conduction disorders).

By analysis of each form of tachyarrhythmia in the anterior and diaphragmal localization of infarction, it was shown that tachyarhythmias were more frequent in the anterior STEMI, i.e. that ST was the most frequent form of rhythm disorder associated with the anterior localization of infarction that occurs exclusively within the first 4 hrs. According to data from the literature, in about $1 / 3$ of patients with AMI ST usually occurs within the first days after infarction, and particularly in patients with anterior infarction [19]. This leads to the increased demand of the myocardium for oxygen as well as to a reduced time necessary for coronary perfusion. Persistent ST results in the development of weak heart. Single VES are more frequent in the diaphragmal localization. The frequency of VT in both localizations is almost identical, while VF is statistically significantly more frequent in infarction of anterior localization. The occurrence of VF in the diaphragmal STEMI was recorded only in the first $4 \mathrm{hrs}$. AF is a rhythm disorder that develops significantly in the period from $5-12$ hrs.

Coronary arterial disease is the leading cause of death worldwide [1]. It is the cause of death in $45,6 \%$ of cases in the developed countries and in $24.5 \%$ of cases in the developing countries. The analysis of the cause of death has shown that infarct complications, primarily severe ventricular arrhythmias and weak heart, are still the main reason of such a high mortality rate. In our study 13 
(12/1\%) of ACS patients died, of whom $70 \%$ (9/13) were those with STEMI. Most frequent disorders, which were registered in 5 lethal cases, were those with BBB. Of the total number of lethal cases with STEMI there were 6 with anterior and 3 with diaphragmal localization. Most lethal cases were those with BBB (33.3\%), while the patients with VF and ST were represented by identical rates. Peters et al. [20] also detected increased mortality rate in patients with conduction and supraventricular rhythm disorders. Thus increased mortality rate in patients with ACS associated with BBB is more associated with extensive myocardial damage than with the block itself.

According to data from the literature, a total mortality rate due to STEMI in Serbia in 2004 was $12,4 \%$, and in $200511,7 \%$, hospital mortality due to ACS was $8.2 \%$, and UAP 1,6\% [5]. Also, as reported in the literature, it is well known that in patients with MI mortality rate is highest during the first hours, most often before hospital admis-

\section{References}

1. Van de Werf F, Bax J, Betriu A, et al. Management of acute myocardial infarction in patients presenting with persistent ST-segment elevation: the Task Force on the Management of ST-Segment Elevation Acute Myocardial Infarction of the European Society of Cardiology. Eur Heart J. 2008; 29 (23):2909-45.

2. Fuster $\mathrm{V}$, Moreno $\mathrm{P}$, Fayad Z, et al. Atherothrombosis and high — risk plaque part I evolving concept. J Am Coll Cardiol. 2005; 46:937-54.

3. Ebell M. Evaluation of chest pain in primary care patients. Am Fam Physician. 2011; 83 (5):603-5.

4. O'Connor RE, Bossaert L, Arntz HR, et al. Part 9: acute coronary syndromes: 2010 International Consensus on Cardiopulmonary Resuscitation and Emergency Cardiovascular Care Science With Treatment Recommendations. Circulation. 2010;122 (16 Suppl 2): S422-65.

5. Vasiljević Z, Mickovski-Katalina N. Klinička obeležja, lečenje i smrtnost bolesnika sa akutnim koronarnim sindromom u Srbiji od 2002. do 2005. godine: analiza podataka nacionalnog registra za akutni koronarni sindrom. Srpski arhiv. 2007; 11-12: 645-53.

6. Gurm HS, Gore JM, Anderson FA Jr, et al. Comparison of Acute Coronary Syndrome in Patients Receiving Versus Not Receiving Chronic Dialysis (from the Global Registry of Acute Coronary Events [GRACE] Registry). Am J Cardiol. 2012; 109 (1):19-25

7. Mandelzweig L, Battler A, Boyko V, et al. For the Euro Heart Survey Investigators. The second Euro Heart Survey on acute coronary syndromes: Characteristics, treatment and outcome of patients with ACS in Europe and the Mediterranean basin in 2004. Eur Heart J 2006; 27 (19); 2285-93.

8. Perron AD, Sweeney T. Arrhythmic complications of acute coronary syndromes. Department of Emergency Medicine, Maine Medical Center, Portland, 04102, USA. Emerg Med Clin North Am. 2005 Nov; 23 (4):1065-82.

9. Meltzer LE, Cohen HE. The incidence of arrhythmias associated with acute myocardial infarction. In: Meltzer LE, Dunning AJ (eds). Textbook of Coronary Care. Philadelphia: Charles Press, 1972. sion and it ranges between 30-50\%, while hospital mortality rate ranges from $10-15 \%$, and within the first year from $5-10 \%$.

\section{Conclusion}

As presented in our paper, heart rhythm and conduction disorders are one of the leading causes of death in patients with ACS during the first hours after the onset of complaints. In order to decrease mortality rate, it is necessary to apply some of the measures regarding the education of risk population, i.e. patients with some of the forms of coronary disease, but it is also necessary to have available educated teams in the sector of emergency medicine. Future researches should be directed toward the determination of highly methods for early prehospital screening of heart rhythm and conduction disorders in ACS so as to act on time preventively and therapeutically.

10. Antman EM, Braunwald E. Acute myocardial infarction. Arrhythmias In: Braunwald E. (ed): Heart Disease. A textbook of cardiovascular medicine, 6th ed. Philadelphia: W.B. SAUNDERS, 2001:1184-1288.

11. Kyriakidis M, Barbetseas $\mathrm{J}$, Antonopoulos $\mathrm{A}$ et al. Early atrial arrhythmias in acute myocardial infarction: role of the sinus node artery. Chest 1992; 101:944-947.

12. Pizzetti F, Turazza FM, Franzosi MG, et al. Incidence and prognostic significance of atrial fibrillation in acute myocardial infarction: the GISSI-3 data. Heart. 2001; 86 (5):527-32.

13. Sugi K Strategy for cardiac arrhythmias in acute coronary syndrome. Nihon Rinsho. 2006; 64 (4):729-33.

14. Kyriakidis, M, Barbetseas J, Antonopoulos A, et al. Early atrial arrhythmias in acute myocardial infarction. Role of sinus node artery. Chest 1992; 101:944-7.

15. Vasiljević-Pokrajčić Zorana, Stefanović B. Akutni infarkt miokarda - Koronarna bolest, In: Nedeljković S., Kanjuh V., Vukotić M. (ed). Kardiologija. Beograd: Medicinski fakultet, 2000: 1146-58.

16. Joint European Society of Cardiology/American College of Cardiology Committee Myocardial infarction redefined: a Consencus Document of the Joint European Society of Cardiology/American College of Cardiology Committee for the redefinition of myocardial infarction. Eur Heart J 2000; 21:1502-13.

17. TIMI Study Group: The thrombolysis in myocardial infarction (TIMI Trial): Phase and findings. N. Engl. J. Med. 1985; 312:932.

18. Uznańska-Loch B, Cieślik-Guerra U, Rechciński T, et al. One patient - many faces of myocardial ischaemia. Kardiol Pol. 2013; 71 (6):631-3. doi: 10.5603/KP.2013.0132.

19. Crimm A, Severance HW, Coffey K, et al. Prognostic significance of isolated sinus tachycardia during the first three days of acute myocardial infarction. Am J Med 1984; 76 : 983.

20. Peters NS, Schilling RJ, Canagaratnam $P$, Markides V. Atrial fibrillation: Strategies to control, combat and cure. Lancet 2002; 359:593-603. 